Decision Analysis of Mitigation and Remediation of Sedimentation Within Large Wetland Systems-A Case Study Using Agassiz National Wildlife Refuge

By Max Post van der Burg, Karen E. Jenni, Timothy L. Nieman, Josh D. Eash and Gregory A. Knutsen

Open-File Report 2014-1180

U.S. Department of the Interior

U.S. Geological Survey 


\section{U.S. Department of the Interior \\ SALLY JEWELL, Secretary}

\section{U.S. Geological Survey \\ Suzette M. Kimball, Acting Director}

U.S. Geological Survey, Reston, Virginia: 2014

For more information on the USGS-the Federal source for science about the Earth, its natural and living resources, natural hazards, and the environment-visit http://www. usgs.gov or call 1-888-ASK-USGS

For an overview of USGS information products, including maps, imagery, and publications, visit $h$ ttp://www.usgs.gov/pubprod

To order this and other USGS information products, visit http://store.usgs.gov

Any use of trade, firm, or product names is for descriptive purposes only and does not imply endorsement by the U.S. Government.

Although this information product, for the most part, is in the public domain, it also may contain copyrighted materials as noted in the text. Permission to reproduce copyrighted items must be secured from the copyright owner.

Suggested citation:

Post van der Burg, Max, Jenni, K.E., Nieman, T.L., Eash, J.D., and Knutsen, G.A., 2014, Decision analysis of mitigation and remediation of sedimentation within large wetland systems-A case study using Agassiz National Wildlife Refuge: U.S. Geological Survey Open-File Report 2014-1180, 24 p., http://dx.doi.org/10.3133/ofr20141180.

ISSN 2331-1258 (online) 


\section{Contents}

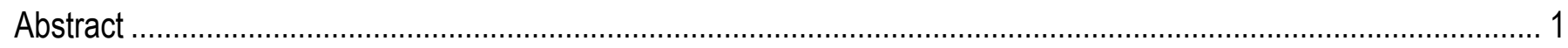

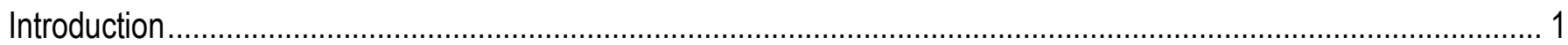

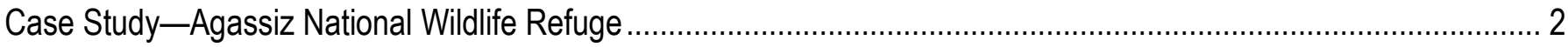

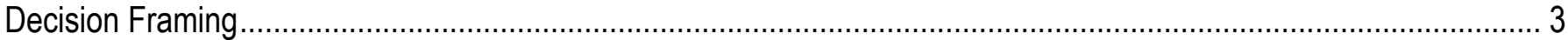

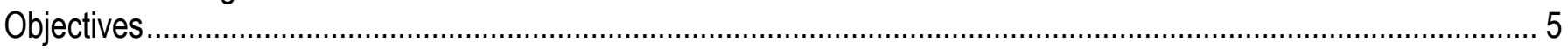

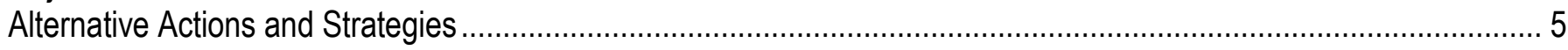

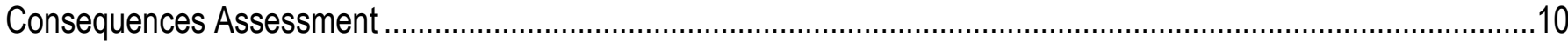

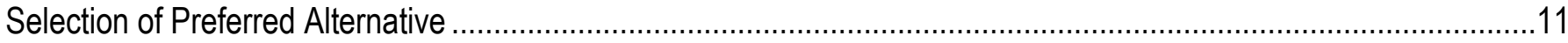

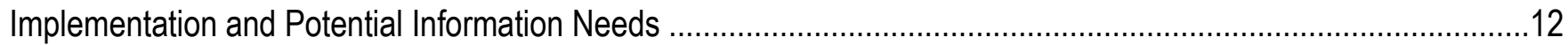

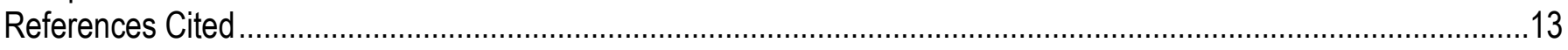

Appendix I. Qualitative Consequences Table................................................................................................ 


\section{Figures}

Figure 1. Location of the Agassiz National Wildlife Refuge within the state of Minnesota. ................................... 3

Figure 2. Location of the Agassiz Pool within the Agassiz National Wildlife Refuge......................................... 4

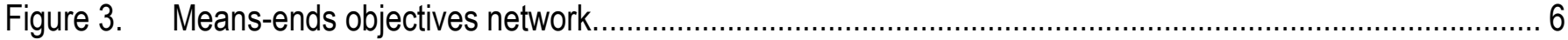

Figure 4. Consequences table showing the impact of three focal strategies on Refuge management objectives. . 15

\section{Tables}

Table 1. Strategy generation table composed of action types and specific alternative actions that can be combined into strategies.

Table 2. Summary table describing evaluated strategies.

Table 3. Simplified table showing general results of the initial consequences assessment. The descriptions in each cell represent the change in performance over the next several decades on each objective relative to conditions at the time of the workshop (see table 4 in appendix I).

Table 4. Consequences table showing the impact of three focal strategies on Refuge management objectives. . 15 


\section{Conversion Factors}

Inch/Pound to SI

\begin{tabular}{lll}
\hline & \multicolumn{1}{c}{ Multiply } & \multicolumn{1}{c}{ To obtain } \\
\hline foot $(\mathrm{ft})$ & Length & \\
mile $(\mathrm{mi})$ & 0.3048 & meter $(\mathrm{m})$ \\
\hline & 1.609 & kilometer $(\mathrm{km})$ \\
\hline acre & Area & \\
\hline & 0.4047 & hectare (ha) \\
\hline ton per year (ton/yr) & Mass & \\
\hline
\end{tabular}




\section{Abbreviations}

PPR

RLWD

SCWRS

SWAT

TRW

FWS

USGS prairie pothole region

Red Lake Watershed district

St. Croix Watershed research station

Soil and water assessment tool

Thief River Watershed

U.S. Fish and Wildlife Service

U.S. Geological Survey 


\title{
Decision Analysis of Mitigation and Remediation of Sedimentation Within Large Wetland Systems-A Case Study Using Agassiz National Wildlife Refuge
}

\author{
By Max Post van der Burg${ }^{1}$, Karen E. Jenni², Timothy L. Nieman ${ }^{3}$, Josh D. Eash ${ }^{4}$ and Gregory A. Knutsen ${ }^{4}$
}

\begin{abstract}
Sedimentation has been identified as an important stressor across a range of wetland systems. The U.S. Fish and Wildlife Service has the responsibility of maintaining wetlands within its National Wildlife Refuge System for use by migratory waterbirds and other wildlife. Many of these wetlands could be negatively affected by accelerated rates of sedimentation, especially those located in agricultural parts of the landscape. In this report we document the results of a decision analysis project designed to help U.S. Fish and Wildlife Service staff at the Agassiz National Wildlife Refuge (herein referred to as the Refuge) determine a strategy for managing and mitigating the negative effects of sediment loading within Refuge wetlands. The Refuge's largest wetland, Agassiz Pool, has accumulated so much sediment that it has become dominated by hybrid cattail (Typha $\times$ glauca), and the ability of the staff to control water levels in the Agassiz Pool has been substantially reduced. This project consisted of a workshop with Refuge staff, local and regional stakeholders, and several technical and scientific experts. At the workshop we established Refuge management and stakeholder objectives, a range of possible management strategies, and assessed the consequences of those strategies. After deliberating a range of actions, the staff chose to consider the following three strategies: (1) an inexpensive strategy, which largely focused on using outreach to reduce external sediment inputs to the Refuge; (2) the most expensive option, which built on the first option and relied on additional infrastructure changes to the Refuge to increase management capacity; and (3) a strategy that was less expensive than strategy 2 and relied mostly on existing infrastructure to improve management capacity. Despite the fact that our assessments were qualitative, Refuge staff decided they had enough information to select the third strategy. Following our qualitative assessment, we discussed additional considerations and uncertainties that might affect implementation of this strategy.
\end{abstract}

\section{Introduction}

Sedimentation has been identified as an important stressor across a range of wetland systems (Barendregt and Swarth, 2013; Burris and Skagen, 2013). Among wetlands in the Great Plains, sedimentation has been determined to negatively affect native plant community composition (Gleason and others, 2003; Tsai and others, 2012; Beas and others, 2013), as well as invertebrate and vertebrate populations (Gleason and others, 2003; Venne and others, 2012). The effects of sedimentation are

\footnotetext{
${ }^{1}$ U.S. Geological Survey.

${ }^{2}$ Insight Decisions LLC.

${ }^{3}$ Decision Applications, Inc.

${ }^{4}$ U.S. Fish and Wildlife Service.
} 
especially concerning for federal agencies tasked with protecting and managing wetland systems. Specifically, the U.S. Fish and Wildlife Service (FWS) has the responsibility of maintaining wetlands within its National Wildlife Refuge System for use by migratory waterbirds and other wildlife. Many of these wetlands could be negatively affected by accelerated rates of sedimentation, especially wetlands embedded within agriculturally dominated landscapes. Evidence suggests that wetlands near crop fields have increased rates of sedimentation compared with those located near lands enrolled in habitat conservation programs (Preston and others, 2013). Likewise, many refuge wetlands are located on river systems, and such flow-through wetland systems can function as sediment traps (Kreiling and others, 2013).

Refuge wetlands that are affected by sedimentation are generally considered to be much more difficult to manage than unaffected wetland systems. One of the main problems facing refuges with sedimentation problems is how to proceed with sediment mitigation and remediation projects given multiple management options, a limited budget, and uncertainties about system response to sedimentation and management actions. Wetland managers would benefit from a structured framework within which they could develop and evaluate potential management strategies. We used one such process and framework by considering mitigation and remediation options for the Agassiz National Wildlife Refuge (herein referred to as the Refuge). The Refuge lies on the eastern edge of the prairie pothole region (PPR) of the United States. We used the principles of decision analysis (Clemen and Reilly, 2001; Keeney and Gregory, 2002) to develop a common framework for articulating and evaluating alternative approaches to mitigating and remediating sedimentation, and to identify the objectives and criteria against which those alternative approaches should be compared. This structure was defined with input from stakeholders ranging from private land owners to municipal and county officials, who had expressed interest in the management of the Refuge.

\section{Case Study-Agassiz National Wildlife Refuge}

The Refuge is a 24,890-ha (61,500-ac) complex of wetlands and uplands located within the Thief River Watershed (TRW) in northwestern Minnesota (fig. 1). Wetlands and shallow, open water pools, including 21 managed impoundments, cover roughly 15,000 ha of the Refuge. These wetlands are maintained and regulated through a system of ditches and water control structures to create a variety of wetland types for the primary purpose of supporting breeding migratory waterbirds. The Refuge lies along the far eastern edge of the PPR. Its location between the tallgrass prairie to the south and west, and the boreal forest to the north and east creates a diversity of wildlife and habitat on the Refuge. However, since European settlement, the landscape has changed dramatically on the Refuge and throughout the Thief River watershed that surrounds it (fig. 1). More specifically, agriculture is the primary land use in the area and drainage is facilitated by more than $1,930 \mathrm{~km}(1,200 \mathrm{mi})$ of county, state, and judicial ditches (Hanson, 2010).

Several tributaries within the Thief River watershed flow into and through the Refuge. In 2006, these tributaries were designated by the Minnesota Pollution Control Agency and the Environmental Protection Agency as impaired waters because of increased turbidity, low dissolved oxygen, and the presence of un-ionized ammonia. Consequently, multiple cooperative water quality investigations were initiated within the TRW to quantify the amount and source of sediments and contaminants flowing into and out of the Refuge (Hanson, 2010; Houston Engineering, Inc., 2010). 


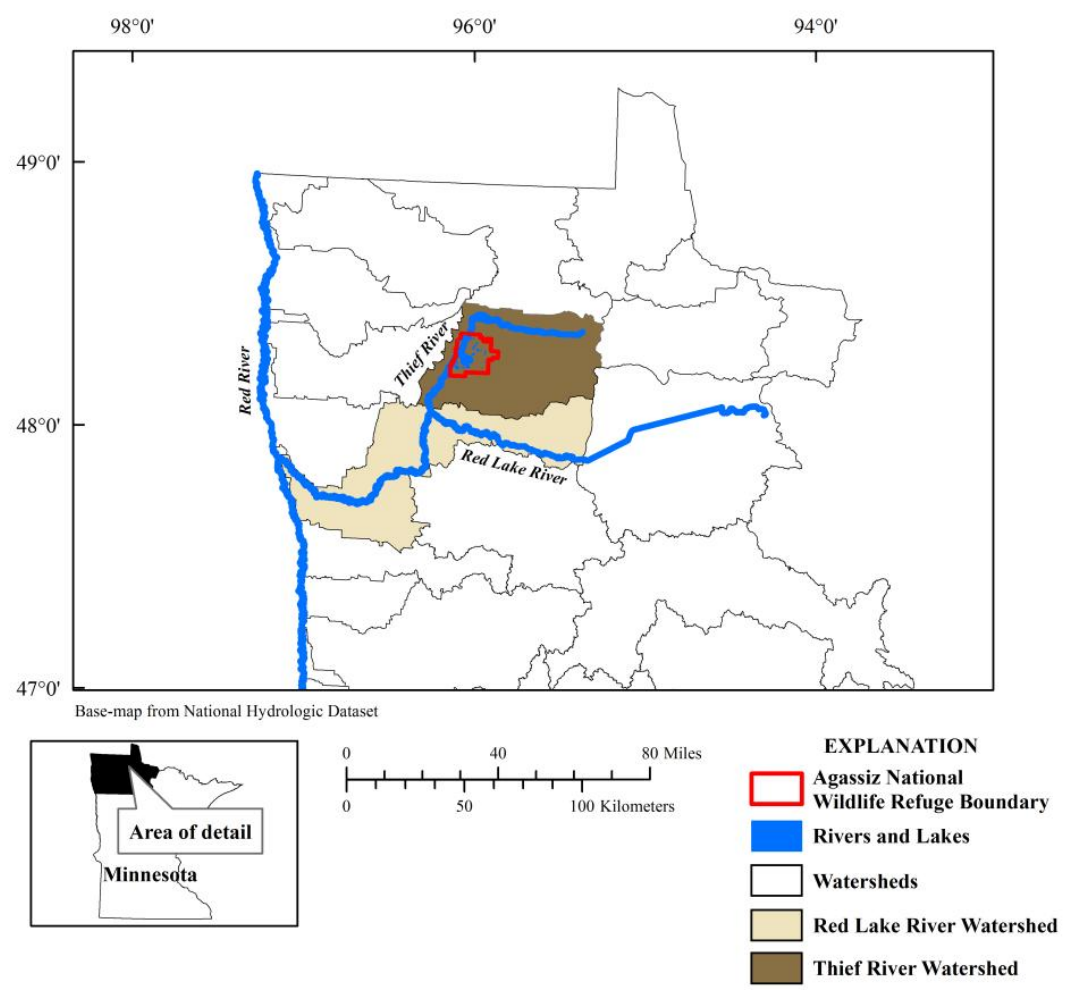

Figure 1. Location of the Agassiz National Wildlife Refuge within the state of Minnesota.

Our case study focused on sedimentation in the Pool. Inorganic sediments enter the Pool from two primary sources: (1) the Thief River flowing through the northwest corner of the Refuge, and (2) Ditch 11, which has two distributaries that flow through the Pool; one main distributary is from east to west, and another from the northeast to southwest along parts of the former Mud River channel (Diversion ditch; fig. 2). The Refuge has some control over water levels in the Pool through the primary water control structure on the west end of Ditch 11. Most of the management options considered relate to different ways to control the Pool's inputs and outputs through these sources. Managing the flow of water out of the Pool has become increasingly difficult because Ditch 11 has effectively filled in with sediment, which makes any attempted drawdowns of the Pool largely ineffective. Effective drawdowns are considered by Refuge staff to be critical for maintaining the health and function of the Pool.

\section{Decision Framing}

A workshop was held in May of 2012 with Refuge staff, local and regional stakeholders, and several technical and scientific advisors. The goals of the workshop were to do the following: 


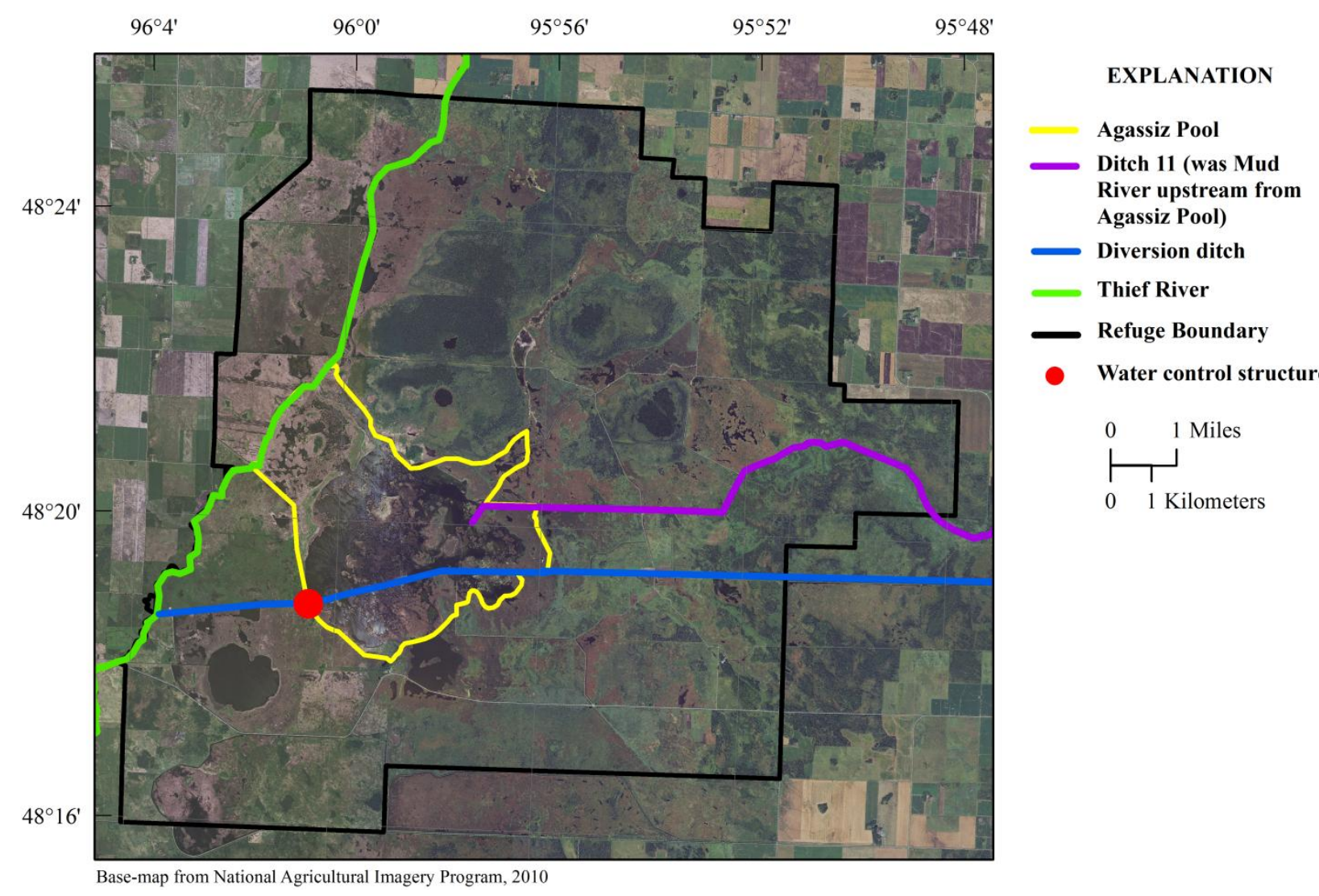

Figure 2. Location of the Agassiz Pool within the Agassiz National Wildlife Refuge.

1. Develop a shared understanding among participants of the condition of the Pool and USFWS management objectives for the Refuge.

2. Develop an improved understanding of the political, economic, and social objectives and constraints that may be affected by the future management of the Pool.

3. Build a conceptual model linking multiple objectives, processes and threats, and multiple management options for the Pool. Although the focus of this study is on sedimentation, other processes and threats (for example, expansion of hybrid cattail) may interact to exacerbate the effects of sedimentation, and the conceptual model should include those factors.

The approach of convening decision framing workshops associated with challenging management problems within the FWS has become increasingly more common as a result of training programs administered through the National Conservation Training Center in collaboration with the U.S. Geological Survey (USGS). The USGS has successfully used such approaches in a range of arenas from environmental contaminants (Coleman and others, 2006) to watershed management (Jenni and others, 2013), and identifying information needs for landscape-level management problems (Woodward and others, 2014). Typically the process of decision framing involves specifying aspects of the decision to be made (such as spatial, temporal, or regulatory considerations); the objectives of those decisions; alternative actions or strategies, often from several perspectives, and an assessment of the consequences of those actions in terms of the objectives. Because the workshops are of limited time (often 2 to 3 days), the subsequent assessment of consequences often changes. The team may initially assess 
alternative strategies using qualitative methods, and move towards a quantified decision model to assess decision alternatives as necessary. The approach used in this case study was one of requisite decision modeling (Phillips, 1984), and the model elements were developed iteratively by the decision analysts and the decision makers to add quantification and complexity only where necessary to increase confidence in the model results and insights. A requisite model is reached when adding to the model no longer adds useful insights for the decision-maker.

\section{Objectives}

Workshop participants identified outcomes of interest (fundamental objectives) for the various decision-makers and stakeholders with concerns about how the Refuge is managed. Stakeholders included upstream landowners whose actions affect sedimentation and downstream representatives, who are potentially affected by sedimentation or potential actions to address sedimentation. Additionally, stakeholders who are agricultural producers have a special interest in Refuge water management actions because of the effect some of those actions can have on agricultural field condition (wetness) upstream and downstream from the Refuge. We developed the following two sets of objectives: (1) from the perspective of the USFWS and Refuge management, and (2) from the perspective of local stakeholders. Together these fundamental objectives (fig. 3) represent some of the main reasons for the existence of the Refuge and some of the main benefits the Refuge provides to surrounding communities. Measuring or estimating these outcomes can be quite challenging (for example, increasing species health and populations for managed species), and in some cases technical experts expressed significant skepticism that such an objective would be measureable.

Through subsequent discussions, we identified a second tier of objectives, which were considered easier to estimate and were connected to the fundamental objectives. We term these means objectives because they represent a possible means for achieving the fundamental objectives (fig. 3; Keeney, 1992). Refuge staff identified the best way to achieve the fundamental biological objectives of Refuge management (the two on the top left of fig. 3) was to improve wetland function and processes. Specifically, to restore the drying-rewetting cycle that has been seen historically in natural prairie wetlands. Key to achieving this is the ability to dry out the Pool by deliberately drawing down the water level, shown in the yellow box in the upper right of figure 3. However, sedimentation is limiting the capacity of Refuge staff to drain the pool. Over the next several decades, sedimentation may actually make it easier to dry the pool because the pool will hold less water, but increased sediment could also make water levels more difficult to control as Ditch 11 fills in and channel capacity decreases.

\section{Alternative Actions and Strategies}

A variety of approaches for mitigating and remediating sedimentation in the Pool were discussed during the workshop. They were organized into four types of mostly independent activities, the first three of which contribute to the ability to dry the Pool. The following are the four types:

- Actions to reduce the sediment loads in water entering the Pool

- Actions to reduce the amount of sediment-laden water entering the Pool

- Actions to reduce the amount of sediment already in the Pool

- Actions to increase wetland habitat diversity (for example, hybrid cattail reduction)

Although the first three types of actions should eventually increase the capacity to manage for more diverse habitat types, the last type of action represents continued active management of cattails on the Refuge. 


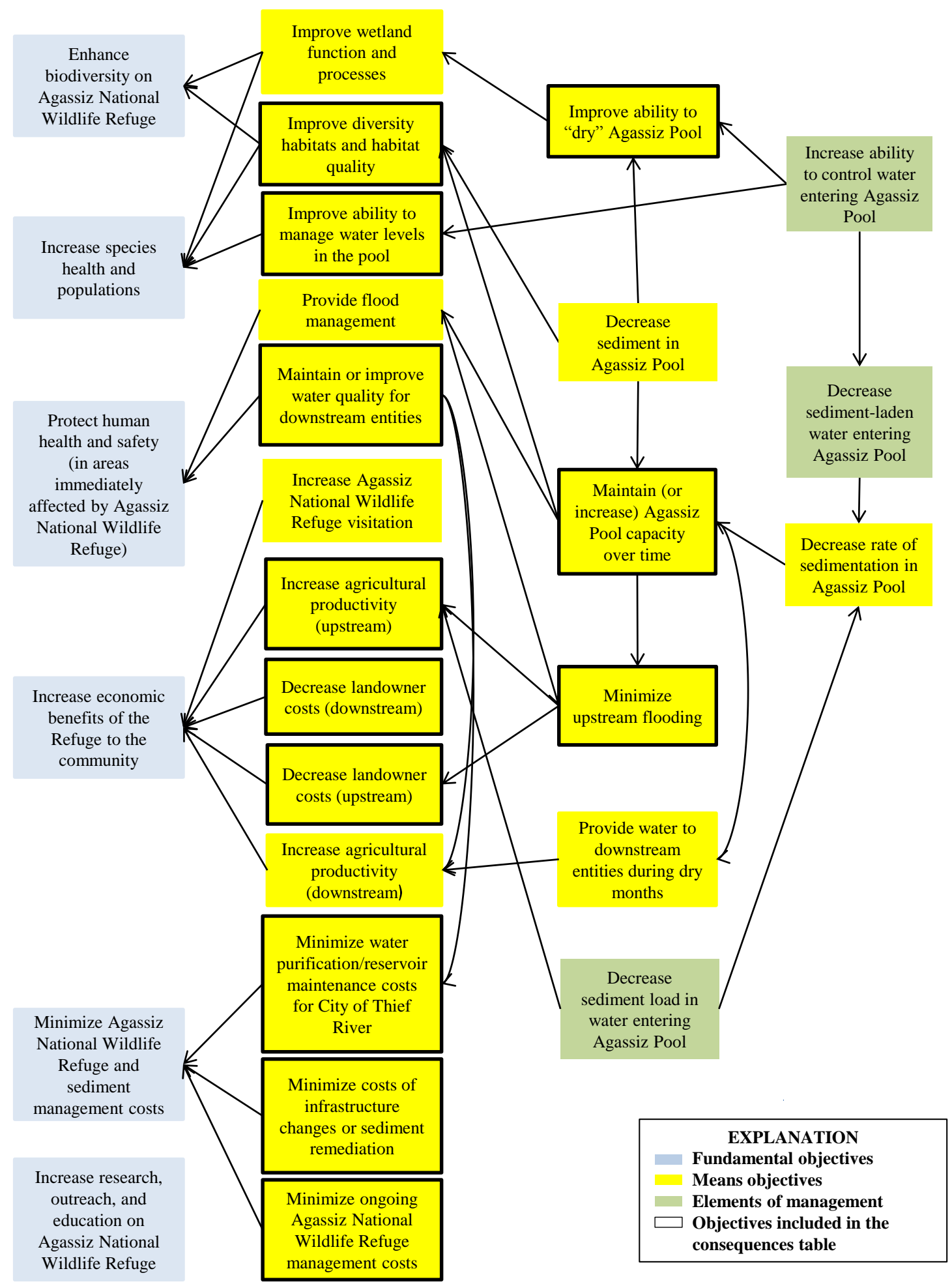

Figure 3. Means-ends objectives network. 
Table 1. Strategy generation table composed of action types and specific alternative actions that can be combined into strategies.

\begin{tabular}{|c|c|c|c|c|}
\hline Action type & \multicolumn{4}{|c|}{ Alternative actions } \\
\hline $\begin{array}{l}\text { Reduce sediment loads } \\
\text { in incoming waters by } \\
\text { working with upstream } \\
\text { landowners }\end{array}$ & $\begin{array}{l}\text { Current level of } \\
\text { effort }\end{array}$ & Increased effort & $\overline{--}$ & $\overline{--}$ \\
\hline Sediment traps & None & Physical traps & Vegetative traps & -- \\
\hline Thief River bypass & No & Yes & -- & -- \\
\hline Mud River diversion & No action & Reconnect to Mud River & $\begin{array}{c}\text { Water control structure to } \\
\text { allow use or bypass of } \\
\text { diversion }\end{array}$ & -- \\
\hline $\begin{array}{l}\text { Mud River/Ditch } 11 \\
\text { bypass }\end{array}$ & None & South bypass & $\begin{array}{l}\text { Ditch } 11 \text { cleaned and } \\
\text { operated for flow through } \\
\text { (with appropriate control } \\
\text { structures) }\end{array}$ & $\begin{array}{c}\text { Pipe(s) near or } \\
\text { through Ditch } \\
11 .\end{array}$ \\
\hline $\begin{array}{l}\text { Restore natural stream } \\
\text { flow of Mud River }\end{array}$ & No & Yes & -- & -- \\
\hline Ditch 11 modifications & No change & $\begin{array}{l}\text { Incremental physical } \\
\text { cleaning of Ditch } 11 \text { to } \\
\text { enhance natural flushing }\end{array}$ & $\begin{array}{c}\text { Full cleanout of Ditch } 11 \\
\text { and installation of } \\
\text { controls (to allow } \\
\text { operation as "flow } \\
\text { through") }\end{array}$ & -- \\
\hline $\begin{array}{l}\text { Sediment removal from } \\
\text { Agassiz Pool }\end{array}$ & None & $\begin{array}{l}\text { Use flushing and scouring } \\
\text { to remove sediment during } \\
\text { drawdowns }\end{array}$ & $\begin{array}{l}\text { Physical removal of } \\
\text { sediment from Agassiz } \\
\text { Pool (dredging) }\end{array}$ & -- \\
\hline Cattail management & $\begin{array}{l}\text { Current levels of } \\
\text { effort }\end{array}$ & $\begin{array}{l}\text { Increased effort (burning, } \\
\text { chemical application, } \\
\text { physical removal) }\end{array}$ & -- & -- \\
\hline $\begin{array}{l}\text { Management approaches } \\
\text { to drawdowns }\end{array}$ & No change & $\begin{array}{c}\text { Increase } \\
\text { frequency/duration of } \\
\text { drawdowns }\end{array}$ & -- & -- \\
\hline
\end{tabular}

The Refuge staff developed a strategy generation table (Clemen and Reilly, 2001) with the types of actions they could take (table 1). For example, the first row indicates that with respect to reducing sediment loads in incoming waters by working with landowners, the Refuge can either continue ongoing levels of outreach, or increase that outreach (table 1). Options for addressing sedimentation issues in the Pool can be defined by combining actions from each row of table 1 into strategies. Obviously, there are a large number of possible combinations that could be considered (table 1), and there may be multiple ways in which the specified actions can be carried out. The strategy table was 
used to propose several options for different comprehensive approaches to mitigation and remediation of sedimentation in the Pool (table 1).

Table 2 shows a description of six strategies identified for initial evaluation and comparison. Workshop discussions led to a decision to not pursue approaches involving physical removal of sediment from the Pool via dredging, because of cost, uncertainty about its effectiveness, and the fact that this tactic could be brought back into consideration at any point in the future. Thus, the options shown in table 2 do not include all of the possible actions identified in the strategy generation table, but rather those that the Refuge management team considered likely to be effective and feasible. Each strategy has elements to address sediment loading in water entering the Refuge, water flow into the Pool, and reducing the amount of accumulated sediment within the Pool to increase the ability to manage the Pool effectively (table 2). Below are descriptions of each strategy:

Strategy 1-Management changes and upstream focus.-This strategy focused on doing the most the Refuge can with existing financial resources. It focused on attempting to reduce the amount of sediment loading in the waters entering the Refuge through increased outreach, and on communicating and promoting sediment-reducing agricultural practices and conservation programs to upstream landowners. Within this strategy the Refuge would also change management (table 2) to try to improve the health of the Pool with more frequent drawdowns to achieve better dry-out, and more active management of cattails to try to limit habitat degradation.

Strategy 2-Bypass focus.-This strategy focuses on increasing the ability to manage flows into the Refuge by installing bypasses on the Thief River, the Mud River Diversion, and Ditch 11 (table 2). Refuge staff would continue to expend the on-going level of effort at reducing the amount of sediment loading in water entering the Pool, and would use the same drawdown and cattail management changes described in strategy 1 (table 2).

Strategy 3-Emphasize flushing.-This strategy focused resources on removing existing sediment from the Refuge through flushing and scouring from multiple drawdowns over several years. Flushing would be facilitated by an incremental cleanup of Ditch 11 in the Pool, working from west to east, and occasionally breaching the walls of Ditch 11 to facilitate flow out of the Pool. The Thief River bypass is included to allow better control of sediment entering the Pool from the Thief River. Outreach and programs to reduce agricultural sediments from upstream landowners would continue at on-going levels.

Strategy 4-Engineered strategy .- This strategy focused resources on cleaning out Ditch 11, installing active controls in Ditch 11 where it enters the Pool, and then removing existing sediment from the Pool through flushing and scouring from multiple drawdowns for 10 years (similar to the approach in strategy 3; table 2). The Thief River bypass would be completed to allow better control of sediment entering the Pool. Outreach and programs to reduce agricultural sediments from upstream landowners would continue at on-going levels.

Strategy 5- South bypass and flushing.- This strategy focused on increasing the ability to manage flows into the Pool by installing bypasses for the Thief River and for the Mud River, routing the water that goes through the Pool via Ditch 11 to the south in a new diversion ditch, and removing existing sediment from the Refuge through flushing and scouring from multiple drawdowns and breaches over several years. Flushing would be facilitated by an incremental cleanup of Ditch 11 in the Pool, working from west to east, but for this to be feasible the bypass on the Mud River would have to have some level of active control so that water could be routed into the Pool when desired, and could bypass the Pool when that is preferable. Outreach and programs to reduce agricultural sediments from upstream landowners would continue at on-going levels, and the Refuge would use the same drawdown and cattail management changes described in strategy 1 . 
Strategy 6-Direct bypass and flushing. - This strategy focused on increasing the ability to manage flows into the Pool by installing bypasses for the Thief River and for the Mud River (bypassing Ditch 11 and Diversion Ditch direct bypass), and removing existing sediment from the Refuge through flushing and scouring from multiple drawdowns and breaches over several years. Flushing will be facilitated by an incremental cleanup of Ditch 11 in the Pool, working from west to east, as described in strategy 3. During and after this cleanup, control structures could be installed along Ditch 11, if necessary, to control flow to the Pool. Outreach and programs to reduce agricultural sediments from upstream landowners would continue at on-going levels, and the Refuge would use the same drawdown and cattail management changes described in strategy 1.

Table 2. Summary table describing evaluated strategies.

[Rows in grey have been eliminated from further consideration; rows in green were evaluated in more detail.]

\begin{tabular}{|c|c|c|c|}
\hline \multirow{2}{*}{$\begin{array}{l}\text { Short name for } \\
\text { solution }\end{array}$} & \multicolumn{3}{|c|}{ Key elements of solution } \\
\hline & $\begin{array}{c}\text { Reduce sediment } \\
\text { loading upstream } \\
\text { from Agassiz National } \\
\text { Wildlife Refuge }\end{array}$ & $\begin{array}{l}\text { Control water and } \\
\text { sediment inflow to } \\
\text { Agassiz Pool }\end{array}$ & $\begin{array}{c}\text { Manage Agassiz Pool for sediment } \\
\text { removal }\end{array}$ \\
\hline $\begin{array}{l}\text { 1. Management } \\
\text { changes and } \\
\text { upstream focus }\end{array}$ & $\begin{array}{l}\text { Increased outreach and } \\
\text { focus on practices to } \\
\text { reduce sediment loading }\end{array}$ & No changes & $\begin{array}{l}\text { Management changes aimed and } \\
\text { achieving dry drawdowns }\end{array}$ \\
\hline 2. Bypass focus & $\begin{array}{l}\text { Continuation of existing } \\
\text { outreach and programs }\end{array}$ & $\begin{array}{l}\text { Thief River bypass and } \\
\text { Mud River (including the } \\
\text { diversion)/Ditch } 11 \\
\text { bypass to the south with } \\
\text { active management } \\
\text { structures }\end{array}$ & $\begin{array}{l}\text { Management changes aimed and } \\
\text { achieving dry drawdowns }\end{array}$ \\
\hline $\begin{array}{l}\text { 3. Emphasize } \\
\text { flushing }\end{array}$ & $\begin{array}{l}\text { Continuation of existing } \\
\text { outreach \& programs }\end{array}$ & $\begin{array}{l}\text { Thief River bypass; } \\
\text { reconnect Mud River } \\
\text { diversion to Ditch } 11\end{array}$ & $\begin{array}{l}\text { Incremental/sequential cleanup of } \\
\text { Ditch } 11 \text { in Agassiz Pool, natural } \\
\text { flushing and scouring through } \\
\text { multiple drawdowns during the } \\
\text { course of several years }\end{array}$ \\
\hline $\begin{array}{l}\text { 4. Engineered } \\
\text { strategy }\end{array}$ & $\begin{array}{l}\text { Continuation of existing } \\
\text { outreach \& programs }\end{array}$ & $\begin{array}{l}\text { Thief River bypass; } \\
\text { reconnect Mud River } \\
\text { diversion to Ditch 11; use } \\
\text { flow-through on Ditch } 11 \\
\text { for Mud River bypass }\end{array}$ & $\begin{array}{l}\text { Clear Ditch } 11 \text {, install active } \\
\text { controls, use natural flushing } \\
\text { approach to reduce sediment in } \\
\text { Agassiz Pool and keep Ditch } 11 \text { from } \\
\text { filling in }\end{array}$ \\
\hline $\begin{array}{l}\text { 5. South bypass } \\
\text { and flushing }\end{array}$ & $\begin{array}{l}\text { Continuation of existing } \\
\text { outreach and programs }\end{array}$ & $\begin{array}{l}\text { Thief River bypass and } \\
\text { Mud River/Ditch } 11 \\
\text { bypass to the south with } \\
\text { active management } \\
\text { structures }\end{array}$ & $\begin{array}{l}\text { Incremental/sequential cleanup of } \\
\text { Ditch } 11 \text { in Agassiz Pool, natural } \\
\text { flushing and scouring through } \\
\text { multiple drawdowns during the } \\
\text { course of several years }\end{array}$ \\
\hline $\begin{array}{l}\text { 6. "Direct" } \\
\text { bypasses and } \\
\text { flushing }\end{array}$ & $\begin{array}{l}\text { Continuation of existing } \\
\text { outreach and programs }\end{array}$ & $\begin{array}{l}\text { Thief River bypass and } \\
\text { Mud River/Ditch } 11 \\
\text { direct bypass }\end{array}$ & $\begin{array}{l}\text { Incremental/sequential cleanup of } \\
\text { Ditch } 11 \text { in Agassiz Pool, natural } \\
\text { flushing and scouring through } \\
\text { multiple drawdowns during the } \\
\text { course of several years }\end{array}$ \\
\hline
\end{tabular}




\section{Consequences Assessment}

A preliminary consequences assessment is located in table 3. The initial assessment involved only the first four strategies, which had been developed at the workshop, and was composed only of a general assessment of the direction and size of effect on each of the objectives. Strategies 5 and 6 were developed by the Refuge management team following this initial assessment, and were specifically developed as combinations of the most beneficial aspects of strategies 2,3 , and 4 . With the addition of these hybrid strategies, the team decided to focus on more comprehensive comparisons of strategies 1 , 5 , and 6 only (table 3). The Refuge management team qualitatively assessed the effects of these three focal strategies on management objectives based on their professional experience. Refuge staff began a more quantitative assessment of these strategies, but they concluded that the qualitative assessment was sufficient for them to choose a preferred alternative so the quantitative analysis was not completed. A more detailed qualitative assessment can be located in appendix I.

Table 3. Simplified table showing general results of the initial consequences assessment. The descriptions in each cell represent the change in performance over the next several decades on each objective relative to conditions at the time of the workshop (see table 4 in appendix I).

[Rows in grey were eliminated from further consideration; rows in green were evaluated in more detail (see table 4 in appendix I). Agassiz National Wildlife Refuge is referred to simply as "Refuge".]

\begin{tabular}{|c|c|c|c|c|c|c|c|c|c|c|}
\hline & \multicolumn{10}{|c|}{ Objectives } \\
\hline Strategies & $\begin{array}{c}\text { Dry } \\
\text { Agassiz } \\
\text { Pool }\end{array}$ & $\begin{array}{c}\text { Manage } \\
\text { water } \\
\text { levels }\end{array}$ & $\begin{array}{l}\text { Wetland } \\
\text { habitats }\end{array}$ & $\begin{array}{c}\text { Water } \\
\text { storage } \\
\text { capacity }\end{array}$ & Drainage & $\begin{array}{l}\text { Downstream } \\
\text { water quality }\end{array}$ & $\begin{array}{c}\text { Short } \\
\text { term } \\
\text { Refuge } \\
\text { costs }\end{array}$ & $\begin{array}{c}\text { Long } \\
\text { term } \\
\text { Refuge } \\
\text { costs }\end{array}$ & $\begin{array}{l}\text { Upstream } \\
\text { costs }\end{array}$ & $\begin{array}{c}\text { Effects on } \\
\text { downstream } \\
\text { entities }\end{array}$ \\
\hline 1 & $\begin{array}{c}\text { Slight } \\
\text { increase }\end{array}$ & Decrease & Decrease & Decrease & Decrease & Decrease & $\begin{array}{l}\text { Slight } \\
\text { increase }\end{array}$ & Increase & $\begin{array}{c}\text { Slight } \\
\text { increase }\end{array}$ & $\begin{array}{c}\text { Slight } \\
\text { decrease }\end{array}$ \\
\hline 2 & Increase & Increase & Increase & $\begin{array}{c}\text { No } \\
\text { change }\end{array}$ & Increase & Decrease & $\begin{array}{c}\text { Large } \\
\text { increase }\end{array}$ & Increase & $\begin{array}{c}\text { No } \\
\text { change }\end{array}$ & Increase \\
\hline 3 & Increase & Increase & Increase & $\begin{array}{c}\text { No } \\
\text { change }\end{array}$ & Increase & Decrease & Increase & $\begin{array}{c}\text { Slight } \\
\text { increase }\end{array}$ & $\begin{array}{c}\text { Slight } \\
\text { increase }\end{array}$ & Increase \\
\hline 4 & $\begin{array}{c}\text { Large } \\
\text { increase }\end{array}$ & Increase & Increase & Increase & Increase & Decrease & $\begin{array}{c}\text { Large } \\
\text { increase }\end{array}$ & $\begin{array}{c}\text { Large } \\
\text { increase }\end{array}$ & $\begin{array}{c}\text { No } \\
\text { change }\end{array}$ & Increase \\
\hline 5 & $\begin{array}{c}\text { Large } \\
\text { increase }\end{array}$ & $\begin{array}{c}\text { Large } \\
\text { increase }\end{array}$ & Increase & Increase & $\begin{array}{c}\text { Large } \\
\text { increase }\end{array}$ & Increase & $\begin{array}{c}\text { Large } \\
\text { increase }\end{array}$ & Increase & $\begin{array}{c}\text { Slight } \\
\text { increase }\end{array}$ & $\begin{array}{l}\text { Slight } \\
\text { increase }\end{array}$ \\
\hline 6 & $\begin{array}{c}\text { Large } \\
\text { increase }\end{array}$ & Increase & Increase & $\begin{array}{c}\text { Large } \\
\text { increase }\end{array}$ & Increase & $\begin{array}{c}\text { Slight } \\
\text { increase }\end{array}$ & Increase & Increase & $\begin{array}{c}\text { Slight } \\
\text { increase }\end{array}$ & $\begin{array}{c}\text { Slight } \\
\text { increase }\end{array}$ \\
\hline
\end{tabular}

Strategy 1.- - In general, this strategy was expected to lead to little or no improvement in Refuge management objectives during the next 10 years (table 3). Upstream and downstream benefits would 
also be unlikely as this strategy would maintain the status quo over the same period of time. Of course, the costs over the next decade for this strategy were expected to be comparatively low because the only cost would be for increased staff time for outreach upstream from the Refuge. Over the next several decades, Refuge and off-Refuge objectives were expected to be affected negatively, and the ability to achieve those objectives would continue to decline over time. As a result, management costs were expected to increase because the extent of the sedimentation problem would simply grow, and eventually leave the Refuge in the position of having to continually excavate and dredge sediment in the future. Costs for upstream landowners were not expected to increase; however, the cost of funding for voluntary soil conservation programs was identified as a potential issue.

Strategy 5.- Under this strategy, Refuge staff expected an increase in their ability to meet Refuge management objectives over the next decade and several decades beyond (table 3 ). Refuge staff expected performance on upstream and downstream objectives to improve modestly in the near term, and more appreciable increases in performance of biological objectives. Refuge staff estimated implementation costs and determined that strategy 5 was much more expensive than 1 or 6 (table 3) primarily because of the expense required to build the south bypass. As a point of comparison, staff also considered an option that included all of the strategy 5 components, but included minimal water control structure development associated with the Thief River bypass, which was estimated to cost about $\$ 200,000$ less (out of a total estimated cost of about $\$ 4.9$ million). However, this option was considered only after the evaluation on other objectives was completed, and there was no explicit reconsideration of how that change would affect the ability of the strategy to achieve the level of performance estimated for the original option. The costs accrued over the next several decades under this strategy were expected to be greater than strategy 1 , but only because of a modest increase in staff time and maintenance expenses for water control structures. Refuge staff also thought that there would not be additional costs to upstream landowners since the Refuge's water-level management activities do not directly affect upstream waters. However, downstream waters will likely have increased sediment concentration several times per year. Depending on the timing, these sediment increases (coupled with preexisting water quality impairments) may affect costs to water purification practices by downstream municipalities and necessitate periodic implementation changes. The effects on downstream waters were expected to decrease over the next several decades as the amount of sediment being removed from the Pool via flushing decreases.

Strategy 6.-As described above, this strategy is similar in most aspects to strategy 5 (table 3), but does not include the south bypass. Accordingly, Refuge staff expected that this strategy would provide a similar ability to meet Refuge management objectives. Several key differences were noted. Because this strategy provides fewer options for re-routing water flows, it provides slightly lower flood management capability than does strategy 5 , and may have slightly greater effects on downstream stakeholders. The primary benefit of strategy 6, compared to strategy 5 , was seen as financial (table 3 ). In the next decade, management costs were estimated to be about $\$ 3$ million less than strategy 5. Like strategy 5, staff also considered a version of strategy 6 without the Thief River control structures, and detected a similar, small, cost difference.

\section{Selection of Preferred Alternative}

As Keeney (2004) points out, many kinds of decision problems can be resolved by systematic thinking consistent with decision analysis, and not necessarily by going through an entire quantitative decision analysis. While we set out to use a fully quantified decision analysis, Refuge staff felt confident in choosing to pursue strategy 6 based on the qualitative analysis. This strategy is expected to provide similar benefits to strategy 5 with anticipated lower costs, and offers the opportunity for staged or 
sequential implementation. The potential for staged implementation was attractive to the Refuge in that it allowed them to consider implementing some aspects of the strategy immediately while providing some flexibility to modify later stages of the implementation based on successes (or failures) in the early stages. Although strategies 5 and 6 were recognized to have potential off-Refuge effects that would need careful management, it was the judgment of the Refuge staff that strategy 1, with the lowest offRefuge effects, would lead to continued degradation of the Pool and ultimately to an inability to properly manage the Refuge.

\section{Implementation and Potential Information Needs}

As the Refuge proceeds with strategy 6, several critical uncertainties remain that may bear on the details of how the strategy should be carried out and how effective it will be. In September 2013, Refuge staff held a follow-up meeting with engineering experts to discuss implementation issues. Based on the analysis presented in this report and additional issues identified during the follow-up meeting, a set of critical uncertainties were identified where better information would help in designing and implementing elements of the strategy, as well as improving the Refuge staff's understanding of the effects of the strategy. The qualitative consequences analysis described above was based on an assumption that the strategies would work, but Refuge staff recognize that there are uncertainties about how well they would work. Uncertainties and information needs exist for all of the strategies identified in this project. As such, resolution of these uncertainties could possibly lead to a change in preferences between strategies. Whether or not the preferred strategy changes, resolution of the uncertainties may allow for improved implementation of whatever strategy is ultimately selected. The following questions are ones that Refuge staff identified as possible impediments to effective implementation:

- How much drying of the Pool, in frequency and degree of dryness, is necessary to begin to restore the biological health of the wetland?

- How much sediment removal and how much control of water inflow are necessary to achieve that required level of drying?

- How much sediment can be removed from the Pool over time using the enhanced flushing and scouring approach?

- Will the limited capacity of the Refuge infrastructure to convey water limit the amount of erosional power of water leaving the Pool, thus reducing or eliminating the amount of scouring that occurs? How soon will this occur, if at all?

- How effective will increased outreach to landowners be in terms of promoting sedimentreducing agricultural practices, and when and what level of reduction in sediment loads will occur?

- What will be the effects of increased sediment downstream from the Refuge, either from bypassing or flushing from the Pool?

The Refuge has initiated numerous efforts aimed at reducing these uncertainties and tracking the effects of management actions including water quality monitoring, annual aerial photography, and topographic surveys. These and other efforts may help Refuge staff adjust management actions to meet their objectives. At the engineering-focused workshop, Refuge staff identified specific actions that they could use to reduce some of these uncertainties. One action was to survey and document the extent of the erosion channels in the Pool, and another was to continue to coordinate with other water managers upstream and downstream from the Refuge to discuss options for mitigating concerns about downstream water quality.

Several important implementation choices also hinge on uncertainties. The following, for example, were some of the uncertainties discussed: 
- How much excavation should be done in Ditch 11 each year, and what would be the best spatial distribution of breach points in Ditch 11? What are the most effective water management strategies for scouring previously deposited sediment from the Pool? These choices could potentially be informed by studies focusing on the physical processes of flushing the Pool or by active experimentation during implementation.

- How should the sediment that is excavated from Ditch 11 be disposed of or used (for example, access road construction)?

- Improved understanding of how effective and useful alternative water control structures upstream of the Pool are in terms of the ability of the Refuge to execute the strategy, which would help the Refuge staff select the most cost-effective control structures.

Finally, during the course of the engineering meeting, participants offered advice on additional components that staff should consider adding to their planned strategy. None of these suggestions were evaluated or assessed in any structured way, and should be considered with caution. First, it was suggested that, over the next decade, a less expensive strategy to building the Thief River bypass might be to install a levee or plug between the Thief River and the Pool rather than an active water control structure. Whether such an approach would provide none, some, or all of the benefits anticipated from a water control structure remains to be assessed, and is one of the uncertainties identified above. Second, it was suggested that the Refuge request a release of water from upstream flood control and wildlife impoundments in an attempt to flush the Pool during a period of almost complete drawdown to maintain flow in Ditch 11 and prevent further sedimentation, and potentially provide additional scouring of Ditch 11 after the Pool has reached the desired drawdown levels.

Continued monitoring will be a critical element of assessing whether implementation is successful or not. The articulated objectives identified in this analysis should provide some guidance as to what system responses need to be tracked to determine the success of the chosen strategy. Additionally, other metrics were discussed during the engineering meeting as potential things to monitor, including water quantity and quality of inflows to and outflows from the Pool; to be useful targets of monitoring, these potential monitoring endpoints should be connected to, and provide information on (a) the objectives of the strategy, and (b) one or more of the uncertainties that remain about the strategy and different implementation choices. In the several decades, many of the actions being considered are beyond the scope of the Refuge budget, and the availability of funding to carry out any of the proposed actions will constrain what can be done.

\section{References Cited}

Barendregt, A.A., and Swarth, C.W., 2013, Tidal freshwater wetlands-Variation and changes: Estuaries and Coasts, vol. 36, no. 3, p. 445-456.

Beas, B.J., Smith, L.M., LaGrange, T.G., and Stutheit, R., 2013, Effects of sediment removal on vegetation communities in Rainwater Basin playa wetlands: Journal of Environmental Management, vol. 128, p. 371-379.

Burris, L., and Skagen, S.K, 2013, Modeling sediment accumulation in North American playa wetlands in response to climate change, 1940-2100: Climatic Change, vol. 117, nos. 1-2, p. 69-83.

Clemen, R.T., and Reilly, T., 2001, Making hard decisions: Duxbury, Pacific Grove, Calif., 733 p.

Coleman, J.L., Jr., Taylor, I.L., Nieman, T., and Jenni, K., 2006, A workshop investigating the potential for application of decision analysis principles and processes to geoenvironmental situationsSelenium in West Virginia: U.S. Geological Survey Open-File Report 2006-1283. 
Gleason, R.A., Euliss, N.H., Hubbard, D. E. and Duffy, W.G., 2003, Effects of sediment load on emergence of aquatic invertebrates and plants from wetland soil egg and seed banks: Wetlands, vol. 23 , no. 1 , p. 26-34.

Hanson, C., 2010, Thief River sediment investigation final report: Thief River Falls, Minn., Red Lake Watershed District, 228 p.

Houston Engineering, Inc., 2010, Thief River SWAT modeling Thief River Watershed, MinnesotaNumerical modeling and evaluation of management scenarios: Maple Grove, Minn., Houston Engineering, Inc., 76 p.

Jenni, K., Graves, D., Hardiman, J., Hatten, J., Mastin, M., Mesa, M., Montag, J., Nieman, T., Voss, F., and Maule, A., 2013, Identifying stakeholder-relevant climate change impacts-A case study in the Yakima River Basin, Washington, USA: Climatic Change, vol. 124, nos. 1-2, p. 371-384.

Keeney, R.L., 1992, Value-focused thinking-A path to creative decisionmaking: Cambridge, Harvard University Press, 416 p.

Keeney, R.L., 2004, Making better decision makers: Decision Analysis, vol. 1, no. 4, p. 193-204.

Keeney, R.L., and Gregory, R.S., 2002, Making smarter environmental management decisions: Journal of the American Water Resources Association, vol. 38, no. 6, p. 1601-1612.

Kreiling, R.M., Schubauer-Berigan, J.P., Richardson, W.B., Bartsch, L.A., Hughes, P.E., Cavanaugh, J.C., and Strauss, E.A., 2013, Wetland management reduces sediment and nutrient loading to the upper Mississippi River: Journal of Environmental Quality, vol. 42, no. 2, p. 573-583.

Nustad, R.A., and Galloway, J.M., 2012, Assessment of nutrients and suspended sediment conditions in and near the Agassiz National Wildlife Refuge, Northwest Minnesota, 2008-2010: U.S. Geological Survey Scientific Investigations Report 2012-5112, 45 p.

Phillips, L.D., 1984, A theory of requisite decision models: Acta Psychologica, vol. 56, nos. 1-3, p. 2948.

Preston, T.M., Sojda, R.S., Gleason, R.A., 2013, Sediment accretion rates and sediment composition in Prairie Pothole wetlands under varying land use practices, Montana, United States: Journal of Soil and Water Conservation, vol. 68, no. 3, p. 199-211.

Schottler, S.P., and Engstrom, D.R., 2011, Sediment loading and sources to Agassiz National Wildlife Refuge: St. Croix Watershed Research Station, 22 p.

Tsai, J.S., Venne, L.S., McMurry, S.T., and Smith, L.M., 2012, Local and landscape influences on plant communities in playa wetlands: Journal of Applied Ecology, vol. 49, no. 1, p. 174-181.

Venne, L.S., Tsai, J.S., Cox, S.B., Smith, L.M., and McMurry, S.T., 2012, Amphibian community richness in cropland and grassland playas in the Southern High Plains, USA: Wetlands, vol. 32, no. 4, p. 619-629.

Woodward, A., Liedtke, T., and Jenni, K., 2014, Identifying resource manager information needs for the North Pacific Landscape Conservation Cooperative: U.S. Geological Survey Open-File Report 2014-1032, 54 p., http://dx.doi.org/10.3133/ofr20141032. 


\section{Appendix I. Qualitative Consequences Table.}

Table 4. Consequences table showing the impact of three focal strategies on Refuge management objectives.

[Agassiz National Wildlife Refuge is referred to simply as "Refuge".]

\begin{tabular}{|c|c|}
\hline Objective & Strategy 1 \\
\hline $\begin{array}{l}\text { Improve } \\
\text { ability to dry } \\
\text { Agassiz Pool }\end{array}$ & $\begin{array}{l}\text { Short term (10 years): Slight } \\
\text { improvement expected both for } \\
\text { surface water and soil moisture. } \\
\text { Long term (greater than } \mathbf{1 0} \\
\text { years): As Agassiz Pool fills in } \\
\text { with sediment, may become } \\
\text { easier to dry Agassiz Pool, } \\
\text { simply because Agassiz Pool } \\
\text { will be much smaller (however, } \\
\text { note long-term water level } \\
\text { management issues below). }\end{array}$ \\
\hline
\end{tabular}

Improve ability to manage water levels in Agassiz Pool

\section{Short term (10 years): Little to no change from current water management capabilities will be noticed. The largest water management challenges will continue to be at the extremes: managing floods and implementing effective drawdowns.}

Long term (greater than 10 years): Agassiz Pool will become harder to manage in the long term due to continued high rates of sedimentation, which will likely impede drainage during attempted drawdowns and reduce available volume of Agassiz Pool during flood events. However, long term outreach, education and support of best management practices, and conservation easements will help to improve water quality, and reduce overall runoff reducing the flashiness of the system and improving some water management challenges not only for the Refuge, but the Thief River watershed as a whole.

\begin{tabular}{l} 
Strategy 5 \\
\hline Short term (10 years): Approximately 60 \\
percent of area without surface water; \\
evapotranspiration would lead to lower soil \\
moisture in dry areas; could keep Agassiz \\
Pool dry longer. \\
Long term (greater than $\mathbf{1 0}$ years): \\
Assuming water pathways are formed \\
through scour across the Agassiz Pool as a \\
result of the dynamic water level
\end{tabular}

management, up to $\sim 80 \%$ may be able to be effectively and efficiently dried during most years.

Short term (10 years): Overall ability to achieve desired water levels in Agassiz Pool will increase significantly. Ability to intensively manage inflows will increase dramatically. Ability to manage outflows (achieve drawdown) will improve slightly due to the reduction or elimination of primary source water inputs (design of Ditch 11 bypass may be able to incorporate a drainage component that would further improve the ability to drain Agassiz Pool). Evaoptranspiration rates and local precipitation will be key to determining the ability to effectively drawdown Agassiz Pool. Water drainage will become more and more effective as Ditch 11 is cleared and scour pathways form throughout Agassiz Pool. Regardless, some level of drawdown can be achieved even during wet periods. Long term (greater than 10 years): Ability to manage inflow should remain consistent through the life of the infrastructure, although there will undoubtedly be associated maintenance requirements to maintain the level of performance. Drainage of Agassiz Pool will eventually be very effective with a cleared Ditch 11 and scour pathways that connect most portions of Agassiz Pool. Ability to achieve refuge water level objectives during most years ( 9 out of 10 years).

\begin{abstract}
Strategy 6
Short term (10 years): 60-70 percent

without surface water (based on 1939

photos) north of Ditch 11; 100 percent south of Ditch 11 (dry enough to farm). Long term(greater than 10 years): Dynamic water level management may help to increase the ability to effectively drawdown the Agassiz Pool. Approximately 80 percent dry.
\end{abstract}

Likely to be intensive water level management with numerous new water control structures and the flushing management actions. The main difference between this option and Strategy 5are: 1) Maintenance - it will be necessary to impound water in Ditch 11 during certain periods under this alternative making it susceptible to resedimentation and 2) Drawdowns - Agassiz Pool will not be able to be drawdown during wet periods since the source water and the drain water share the same egress.

Short term (10 years): Ability to manage inflows is significantly improved, similar to strategy 5. Ability to draw down Agassiz Pool is slightly to greatly improved in the near term, due to the clearing of Ditch 11 and the potential increased connectivity from eroded water pathways from flushing. Overall ability to meet water management goals will be significantly improved, but water management goals will still be dictated to some extent by the flushing requirement.

Long term (greater than 10 years): For the most part, it should remain similar to the near-term abilities, although there is the potential for significant sediment redeposition within the dredged Ditch 11 channel and associated water control structures, which may present some management and maintenance issues. 


\begin{tabular}{|c|c|c|}
\hline $\begin{array}{l}\text { Improve } \\
\text { habitat } \\
\text { diversity and } \\
\text { quality }\end{array}$ & $\begin{array}{l}\text { Habitat conditions in Agassiz } \\
\text { Pool continue to decline. } \\
\text { Continued expansion of cattail } \\
\text { and loss of open water. Cattail } \\
\text { problem may be further } \\
\text { exacerbated by more frequent } \\
\text { incomplete drawdowns. } \\
\text { Continued negative impacts to } \\
\text { invertebrate community and } \\
\text { wetland plant emergence from } \\
\text { seedbanks. All of the above will } \\
\text { likely result in declines in }\end{array}$ & $\begin{array}{l}\text { Better overwater nesting success due to } \\
\text { improved ability to manage Agassiz Pool } \\
\text { bounce. Potential improvements in } \\
\text { diversity of aquatic plant and invertebrate } \\
\text { communities over time as sediment inputs } \\
\text { decrease and sediment outputs increase, as } \\
\text { well as an increase in open water area as } \\
\text { sediment is removed. Increased wetland } \\
\text { plant and invertebrate productivity, } \\
\text { improved wetland function (for example, } \\
\text { nutrient cycling), and increased use and } \\
\text { production of wetland-dependent birds. }\end{array}$ \\
\hline
\end{tabular}

waterfowl and other wetland-

dependent bird use and

production.

Maintain (or
increase)
Agassiz Pool
capacity

over time

\section{Short term (10 years):}

Continued decrease in water

storage capacity over time due to sedimentation at near current rates.

\section{Long term (greater than 10} years): Continuing decrease in water storage capacity, although the rate of sedimentation may decrease over time as a result of these efforts

\begin{tabular}{|c|c|}
\hline $\begin{array}{l}\text { Minimize } \\
\text { downstream } \\
\text { flooding }\end{array}$ & $\begin{array}{l}\text { Land and water use practices } \\
\text { aimed at reducing sediments are } \\
\text { likely to also reduce the volume } \\
\text { and increase the timing of } \\
\text { runoff. } \\
\text { Short term (10 years): Unlikely } \\
\text { to notice any measurable } \\
\text { declines in water volumes } \\
\text { entering the Refuge within the } \\
\text { first } 10 \text { years. Volumes of water } \\
\text { stored and passed downstream } \\
\text { would be similar to current } \\
\text { conditions. }\end{array}$ \\
\hline
\end{tabular}

Long term (greater than 10 years): The amount and flashiness of runoff should begin to decline. Due to continued sedimentation within Agassiz Pool, this slight decline in runoff will likely go unnoticed by users immediately downstream of the Refuge will be capable of storing less water and will be forced to pass the majority of flood flows downstream. However, this plan holds the opportunity to reduce runoff at the watershed scale.

Better overwater nesting success due to improved ability to manage Agassiz Pool bounce. Potential improvements in diversity of aquatic plant and invertebrate communities over time as sediment inputs decrease and sediment outputs increase, as well as an increase in open water area as sediment is removed. Increased wetland plant and invertebrate productivity, improved wetland function (for example, nutrient cycling), and increased use and production of wetland-dependent birds.

\section{Short term (10 years): Sediment loading should decrease dramatically and Agassiz Pool should gradually increase in overall capacity as a result of Ditch 11 clearing and scour. \\ Long term (greater than 10 years): Overtime Agassiz Pool will scour sediments as Ditch 11 is cleared out and dynamic water management produces more scour pathways. Scour/fill conditions should reach equilibrium within approximately 20 years and overall water storage capacity will have increased 25-35 percent from current conditions.}

\section{Short term (10 years): Depending on} water management practices this plan holds the opportunity of reserving Agassiz Pool as a large flood storage reservoir for flood flows. However, this would defeat the purpose of installing this infrastructure (reduce sedimentation). If monitoring data showed that flushing techniques could be used to effectively manage sediment loading over time, then the refuge may be able to impound some flood flows with the knowledge and ability of flushing those sediments at a later date.

Long term (greater than 10 years): Similar to near term, although once Ditch 11 is cleared, Agassiz Pool will have gained some additional capacity and cattail expansion/distribution will have been reduced. The refuge may be able to offer similar flood storage capacity to previous management without significant threats to refuge resources.
This plan prevents additional sedimentation and emphasizes sediment removal.

Short term (10 years): Moderate to significant increase in storage capacity with the dredging of Ditch 11, flushing technique and dramatic reduction of sediment loads. Long term (greater than 10 years): Same as near-term. Assuming proper maintenance of Ditch 11, the results seen in the first 10 years should be sustainable.

\section{Short term (10 years): Moderate increase} in storage capacity should provide for more storage, but the bypass and flushing are likely to significantly increase the volume and timing of water sent downstream. Because this plan includes both bypasses and flushing, it is likely to send the most water downstream of any of the three alternatives. 


$\begin{array}{ll}\text { Maintain or } & \text { Short term (10 years): Similar } \\ \text { improve } & \text { to } 2009 .\end{array}$

downstream Long term (greater than 10

water quality years): Would see reductions due to reduced sediment loading.

\begin{tabular}{ll}
\hline Minimize & Increased staff time working \\
Refuge & upstream. \\
infrastructur & \\
e or & \\
sediment & \\
remediation & \\
costs &
\end{tabular}

Minimize ongoing

Refuge costs
Current level of management costs will increase as the challenges of management water levels increase with increased sedimentation. In the long run, substantial costs could be required if sediment must be removed through dredging in the future.
Short term (10 years): Amount of sediment downstream will be proportional to volume of water released and allowed to pass through the refuge without

impoundment. The southern bypass would increase nutrient concentration downstream compared to current conditions.

\section{Long term (greater than 10 years):}

Sediment balance would also decrease downstream due to bypass and internal scouring.

Total cost of about $\$ 4.9$ million.

$\$ 4.5$ million to construct a Ditch 11 bypass (and associated inlet water control structures) that routes water from both Main Ditch 11 and the Diversion Ditch (must be connected upstream of Agassiz Pool) south of Agassiz Pool.

$\$ 57,680$ to have a Region 3 Maintenance Action Team (MAT) clean out Ditch 11 incrementally over a four-year period. $\$ 122,000$ to construct a Thief River bypass. $\$ 112,500$ to construct Agassiz Pool inlet water control structures off the Thief River bypass.

$\$ 150,000$ to add additional flow capabilities to the current Agassiz Pool bypass water control structures (constructed in 2007).

Hypothetical option with no structures on Thief River: Replace the estimated $\$ 234,000$ for the Thief River bypass dike and inlet water control structures with a bypass dike and spillway for $\$ 22,000$. Increased time demands for water management and associated infrastructure maintenance activities will be absorbed by existing Refuge staff; however, when needed, major repairs (for example, water control structure replacement) would be contracted out and additional funds would likely be needed.
Short term (10yr): Most of incoming sediments are passed down stream; over the course of several years increased sediment loading from the scouring.
Total cost of about $\$ 2$ million.

$\$ 86,520$ to have a Region 3 MAT clean out Ditch 11 incrementally over a four-year period and connect the Diversion Ditch to Main Ditch 11 upstream of Agassiz Pool. $\$ 675,000$ (3 X $\$ 225,000)$ to construct three water control structures along new connection ditch. $\$ 122,000$ to construct a Thief River bypass. $\$ 112,500$ to construct Agassiz Pool inlet water control structures off the Thief River bypass.

$\$ 150,000$ to add additional flow capabilities to the current Agassiz Pool Bypass water control structures.

$\$ 900,000$ (4 X \$225,000) to construct four new water control structures ( 2 inlet, 2 outlet) along Ditch 11.

\section{Hypothetical option with no structures on} Thief River: Replace the estimated $\$ 234,000$ for the Thief River bypass dike and inlet water control structures with a bypass dike and spillway for about $\$ 22,000$. Increased time demands for water management and associated infrastructure maintenance activities will be absorbed by existing Refuge staff (likely less ditch maintenance required than solution 5); however, when needed, major repairs (for example, water control structure replacement replacement) would be contracted out and additional funds would likely be needed.

\begin{tabular}{ll}
\hline Minimize & Costs for voluntary programs. \\
upstream & Potentially better crop \\
landowner & production for those \\
costs & implementing those programs.
\end{tabular}
Minimal additional costs to the landowners. Possible benefits include getting in fields earlier in spring when Agassiz Pool is low and having a longer overall growing season. However, Refuge staff might potentially request funding from upstream users (for example, Red Lake Watershed District) to assist in implementation of this solution.
Minimal additional costs to the landowners. Possible benefits include getting in fields earlier in spring when Agassiz Pool is low and having a longer overall growing season. However, Refuge staff might potentially request funding from upstream users (for example, Red Lake Watershed District) to assist in implementation of this solution.




\begin{tabular}{|c|c|c|c|}
\hline $\begin{array}{l}\text { Minimize } \\
\text { downstream } \\
\text { water } \\
\text { treatment } \\
\text { costs }\end{array}$ & $\begin{array}{l}\text { If there is less wildlife on the } \\
\text { Refuge, there will be fewer } \\
\text { visitations to the Refuge and } \\
\text { community. Compared to } \\
\text { Strategies } 5 \text { and } 6 \text {, downstream } \\
\text { entities may have minimally less } \\
\text { flooding risk, and lower ditch } \\
\text { maintenance costs, with less } \\
\text { sediment reaching the city } \\
\text { reservoir. }\end{array}$ & $\begin{array}{l}\text { Short periods of increased sediment loads to } \\
\text { downstream waters several times per year. } \\
\text { Depending on the timing, these increases } \\
\text { may create the need for short term changes } \\
\text { to water purification practices by the } \\
\text { municipality of Thief River Falls during } \\
\text { these periods. }\end{array}$ & $\begin{array}{l}\text { Short periods of increased sediment loads to } \\
\text { downstream waters up to several times per } \\
\text { year. Depending on the timing, these } \\
\text { increases may create the need for short term } \\
\text { changes to water purification practices by } \\
\text { the municipality of Thief River Falls during } \\
\text { these periods. }\end{array}$ \\
\hline
\end{tabular}

